\title{
Anterior Choroidal Artery
}

National Cancer Institute

\section{Source}

National Cancer Institute. Anterior Choroidal Artery. NCI Thesaurus. Code C32083.

An artery, which originates in either the internal carotid artery or the middle cerebral artery, that delivers blood to the choroid plexus. 